\title{
COVID-19 Sürecinde Gelişen Persistan Hıçkırık: Nadir Bir Olgu
}

\section{Persistent Hiccups During COVID-19: A Rare Case}

\author{
${ }^{1}$ Erkut ETÇİOĞLU, ${ }^{2}$ Muhammet Raşit AYDIN \\ ${ }^{1}$ Osmaneli Mustafa Selahattin Çetintaş Devlet Hastanesi, Aile Hekimliği Kliniği, Bilecik, TÜRKIYYE \\ ${ }^{2}$ Sapanca İlçe Devlet Hastanesi, Aile Hekimliği Kliniği, Sakarya, TÜRKIYY \\ Erkut Etçioğlu https://orcid.org/0000-0002-8117-7929 \\ Muhammet Raşit Aydın https://orcid.org/0000-0002-4202-0099
}

\section{ÖZ}

SARS-CoV-2 patogenezinin tanımlanmasından günümüze kadar birçok klinik tablo karşımıza çıkmıştır ve bu klinik tablolara her geçen gün yenileri eklenmektedir. Hastalığıı hem prezentasyonunda hem de hastalık sonrası dönemde farklı belirtiler görülebilmektedir; diyaframın ve interkostal kasların spontan, miyoklonik kasılmaları sonucu olușan hıçırık da bunlardan biridir. Bu olgu sunumunda COVID-19 tanısı aldıktan 12 gün sonra başlayan ve üc gün süren kesintisiz hıçkırık yakınması olan hasta sunulmuștur.

Anahtar Kelimeler: COVID-19, hıçkırık, SARS-CoV-2

\section{ABSTRACT}

Many clinical situations have emerged from the definition of the SARS-CoV-2 pathogenesis to the present day, and new ones are added to these clinical situations every day. Different symptoms can be seen both in the presentation of the disease and in the post-disease period, including hiccups caused by spontaneous, myoclonic contractions of the diaphragm and intercostal muscles. In this case report, a patient with uninterrupted hiccups that started 12 days after being diagnosed with COVID-19 and lasted for three days is presented.

Keywords: COVID-19, hiccups, SARS-CoV-2

\author{
Sorumlu Yazar / Corresponding Author: \\ Muhammet Raşit Aydın \\ Yayın Bilgisi / Article Info: \\ Gönderi Tarihi/ Received: 01/07/2021 \\ Sapanca İlçe Devlet Hastanesi, Aile Hekimliği Kliniği, Sakarya, Kabul Tarihi/ Accepted: 10/10/2021 \\ TURKIYE \\ Online Yayın Tarihi/ Published: 01/12/202 \\ Tel: +90 5355804536 \\ E-mail: muhammata@hotmail.com
}

Atıf/ Cited: Etçioğlu E ve Aydın MR. COVID-19 Sürecinde Gelişen Persistan Hıçkırık: Nadir Bir Olgu. Online Türk Sağlık Bilimleri Dergisi, 2021;6(4):599-602. doi:10.26453/otjhs.960968

\section{GİRIŞ}

SARS-CoV-2 virüsüne bağlı COVID-19 geçiren kişi sayısının artmasıyla ve virüsün geçirdiği mutasyonlarla birlikte hastalık tablosunda farklılıklar ortaya çıkabilmektedir. Viral patogenezin tanımlanmasından günümüze kadar birçok klinik tablo karşımıza çıkmıştır ve halen çıkmaktadır. ${ }^{1}$ Bunlar arasinda ishal, tat kaybı, koku kaybı, cilt döküntüleri, hareket bozuklukları gibi belirtiler; delirium, postural vertigo gibi klinik tablolar görülmektedir ve bunlara yenileri de eklenmektedir. ${ }^{2}$ Hıçkırık, diyaframın ve interkostal kasların istemsiz, tekrarlayan kasılmalarının neden olduğu tam olarak anlaşılmayan bir fenomen olarak tanımlanmıştır. ${ }^{3}$
Hıçkırığın genelde santral sinir sistemi ve gastrointestinal sistem patolojileri sonucu geliştiği belirtilmiştir. Hıçkırık görülme süresine göre üçe ayrılır; 48 saatten az süren hıçkırıklar akut atak olarak, 48 saatten fazla süren hıçkırıklar persistan hıçkırık olarak, bir aydan uzun süren hıçkırıklar ise inatçı hıçkırık olarak tanımlanmaktadır. Hıçkırığın birçok klinik durum için belirti olabildiği gösterilmiştir. Hıçkırığın etiyolojisi, travma ve damar hastalıkları gibi nedenlerden çeşitli antiparkinson ve anti-psikotik ilaçlara, gastroözofageal reflü hastalığına, miyokard enfarktüsüne, çeşitli kanserler ve elektrolit bozukluklarına kadar değişebilir. ${ }^{4}$ Hıçkırık, nadiren de olsa toplum 
kökenli pnömoninin klinik belirtilerinden biri olarak da tanımlanmıştır. Çalışmalarda pnömoni tedavisi sonrası ise hıçkırığın kaybolduğu gözlemlenmiştir. ${ }^{5}$ Bu yazımızda COVID-19 tanısı aldıktan 12 gün sonra başlayan ve üç gün süren kesintisiz hıçkırık yakınması olan bir olgunun sunulması amaçlanmıştır.

\section{OLGU SUNUMU}

Çalışma olgu sunumu olduğu için etik kurul iznine gerek yoktur. Uluslararası etik bildirgelere uygun davranılmış olup hastadan tıbbi verilerinin kullanılabileceğine ilişkin yazılı onamı alınmıştır.

Yetmiş yedi yaşında erkek hasta üç gündür geçmeyen hıçkırık şikâyetiyle acil servise başvurdu. Hastanın öyküsünden; 12 gün önce öksürük ve ateş yüksekliği nedeniyle diş merkez acil servise başvurduğu, burada alınan anamnez ve yapılan tetkikler neticesinde COVID-19 şüpheli olarak değerlendirilip nazofarengeal sürüntü alındığ 1 , alınan örneğin polimeraz zincir reaksiyonu (PCR) incelemesinin pozitif olarak saptandığı ve sekiz gün hastanede takip edildiği öğrenildi.

Genel durumu iyi, oryante ve koopere olan hastanın vital bulgularında; ateş 36,5 santigrat derece, arteryel tansiyon 130/90 $\mathrm{mmHg}$, nabiz $90 \mathrm{atım} /$ dakika, solunum sayıs 24/dakika ve oksijen satürasyonu (oda havasında) \%97 idi.

Özgeçmişinde kronik iskemik kalp rahatsızlığı, konjestif kalp yetmezliği, hipertansiyon, benign prostat hiperplazisi, gastrit tanıları mevcuttu. Kardiyak pacemakerı olan hastanın; olmesartan medoksomil 20 miligram $(\mathrm{mg})+$ hidrokloro tiyazid $12,5 \mathrm{mg}$ peroral (PO) yoldan $1 * 1$ pozolojisinde, silodosin $8 \mathrm{mg}$ PO yoldan $1 * 1$ pozolojisinde, asetilsalisilik asit PO yoldan $100 \mathrm{mg} 1 * 1$ pozolojisinde, dutasterid $0.5 \mathrm{mg}$ PO yoldan $1 * 1$ pozolojisinde, pantoprozol $40 \mathrm{mg}$ PO yoldan $1 * 1$ pozolojisinde kullandığı öğrenildi. Daha önce uzun hıçkırık dönemlerinin olmadığını belirten hastanın soygeçmişinde özellik yoktu. Solunum

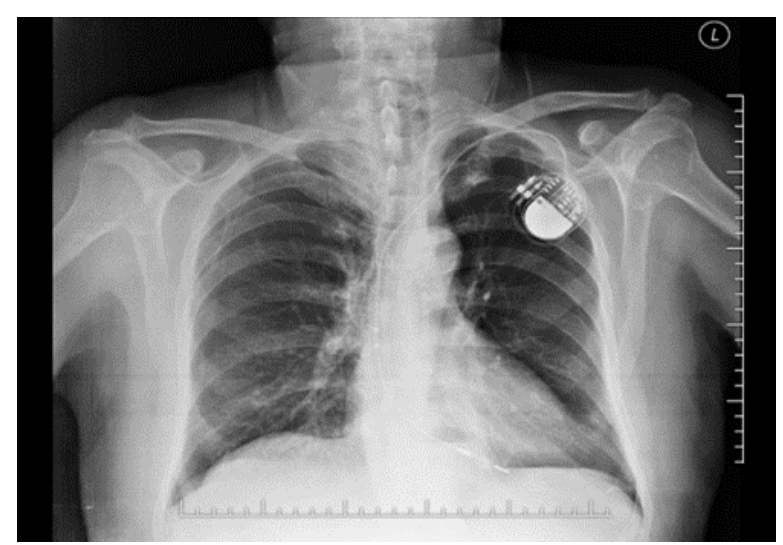

Şekil 1. Hastaya ait posteroanterior akciğer grafi görüntüsü. sistemi oskültasyonunda bazallerde ince raller tespit edilen hastanın, fizik muayenesinde başka patolojik bulgu saptanmad1.

Laboratuvar incelemelerinde; beyaz küre: 9,7 (4,6010,20) K/uL, hemoglobin: 12,4 (12,20-18,10) g/dl, lenfosit: 1,56 (0,60-3,40) K/uL, eosinofil: 0,001 (0,0 -0,7) K/uL, trombosit: $296000(100000-450000) \mathrm{K} /$ uL, laktat dehidrogenaz (LDH): 168 (0-247) U/L, sodyum: 138 (136- 146) mmol/L, potasyum: 4,0 (3,5 $-5,1) \mathrm{mmol} / \mathrm{L}$, kalsiyum: $9,6(8,8-10,6) \mathrm{mg} / \mathrm{dL}$, üre: 33 (17-43) mg/dL, kreatinin: 0,65 (0,67-1,17) mg/ dL, D-dimer: 50 (0-500) ugFEU/L, C-reaktif protein (CRP): 17,6 (0-5) mg/dL, ferritin: $36 \mathrm{ug} / \mathrm{L}$ saptand1. Çekilen posteroanterior akciğer grafisi (PAAC) Şekil 1'de ve lateral akciğer grafisi Şekil 2'de sunulmuştur. Yapılan görüntülemelerde solda pacemaker görüntüsü mevcut olup, sağ akciğer üst ve alt zonda peribronşial duvar kalınlaşması, hafif bronşektazik değişiklikler ve aort topuzu belirginleşmesi dışında patololojik bulgu görülmedi.

Hastanın fiziksel manevralar ile geçmeyen hıçkırığgna yönelik acil serviste öncelikle gastrointestinal kaynaklı olduğu düşünülerek sodyum aljinat + sodyum bikarbonat + kalsiyum karbonat oral suspansiyon formu 10 mililitre (ml) ölçüde PO yoldan verildi. Hastanın hıçkırık şikâyetinin devam etmesi üzerine klorpromazin tedavisi verildi. 500 cc izotonik içerisine bir ampül klorpromazin $\mathrm{HCl}$ koyularak 60 cc/saat hızında intravenöz yoldan infüzyona başland1. İnfüzyonun 30. dakikasında hıçkırığı duran hasta infüzyon sonrası taburcu edildi. Şikâyeti tekrarlarsa tekrar başvurması belirtilerek önerilerde bulunuldu.

\section{TARTIŞMA VE SONUÇ}

Hıçkırık, diyaframın ve çoğu durumda interkostal kasların spontan, miyoklonik kasılmaları sonucu oluşur. Bu koordineli kasılmalar, karakteristik ses ile sonuçlanan glottisin kapanması ile kesintiye uğrayan hızlı bir hava alımına neden olur. Uzamış hıçkırıkla-

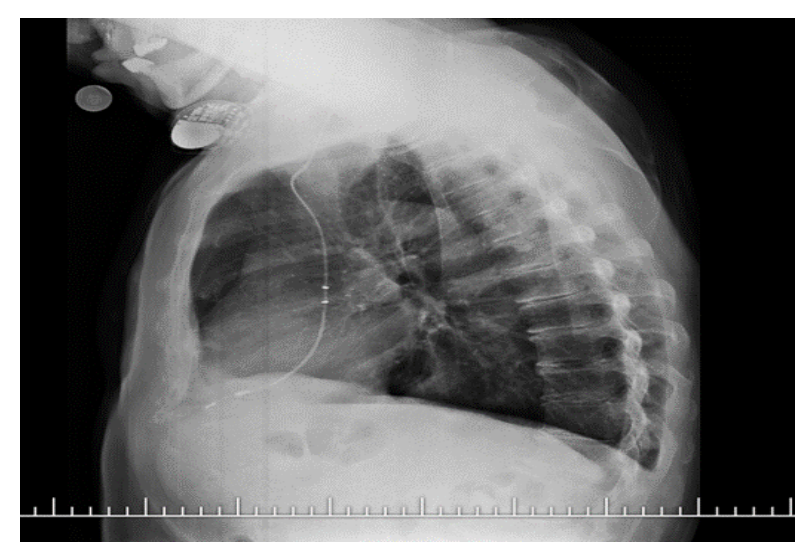

Şekil 2. Hastaya ait lateral akciğer grafi görüntüsü. 
rın nedenleri; merkezi sinir sistemini veya frenik sinirleri ve/veya dallarını etkileyen; yapısal, enfeksiyöz ve inflamatuar bozukluklar olarak üçe ayrılmıştır. Refleks arkı boyunca yer alan sinirlerin uzun seyrinden dolayı hıçkırığın nedenini bulmanın zor olabileceği belirtilmiştir. ${ }^{6}$

Prince ve ark. $^{7}$ son dört aydır istemsiz kilo kaybı olan ve dört gündür aralıksız devam eden hıçkırık öyküsüyle başvuran 62 yaşında erkek hasta sunmuşlardır. Hastanın mevcut şikâyetleri malignite şüphesine yol açtığı ve şikâyetleri arasında hıçkırık olması mediastinal kitle ihtimalini doğurduğu için PAAC görüntülemesini yapmışlardır. PAAC grafide yeni gelişen buzlu cam alanları saptanması üzerine toraks bilgisayarlı tomografi (BT) görüntülemesi istendiği bildirilmiştir. Hastanın takiplerinde mevcut kliniğine ateş yüksekliği ve taşikardi eklendiğini de belirtmişlerdir. Toraks BT görüntülenmesinde akciğer alt loblarındaki pnömoni alanlarının COVID -19 pnömonisi ile uyumlu olabilecek buzlu cam alanları olması ve yapılan nazofarengeal sürüntü örneğinin PCR incelemesinin pozitif saptanmas1 sebebiyle, mevcut başvuru şikâyetlerinin COVID-19 ilişkili olabileceği yönünde görüş bildirmişlerdir. Hıçkırıkla prezente olan bu vaka sunumunun acil tıp literatüründe ilk olgu olduğunu da eklemişlerdir.

Alvarez-Cisneros ve ark. ${ }^{8} 96$ saat boyunca devam eden hıçkırık ile başvuran 48 yaşında bir erkek hastanın yapılan değerlendirmeler neticesinde COVID19 pnömonisi tanısı aldığını bildirmişlerdir. Aynı olgu sunumunda hastanın solunum sistemi oskültasyonunda sol akciğer bazallerde raller tespit etmişlerdir. PAAC grafisi değerlendirmesinde bilateral buzlu cam infiltrasyonu olduğunu ve bu tutulumun COVID-19 pnömonisi ile uyumlu olduğunu belirtmişlerdir. Aynı çalışmada COVID19 pnömonisinde gelişen hıçkırığın en olası nedeninin COVID-19 pnömonisine sekonder gelişen frenik sinir inflamasyonu olabileceğini de eklemişlerdir.

Ikitimur ve ark. ${ }^{9}$ biri COVID-19 tanıs1 konulduktan sonra hıçkırık şikâyeti olan, diğeri hıçkırıkla prezente olup COVID-19 tanısı alan iki olgu tanımlamışlardır. Bu olgu sunumunda; üç gündür aralıksız devam eden hıçkırık şikâyeti olan 60 yaşında erkek hastanın nöroloji kliniğine başvurduğu, nörolojik muayenenin ve beyin manyetik rezonans (MR) görüntülemesinin normal olmasının ardından hıçkırık ayırıcı tanısı için iç hastalıkları departmanına yönlendirildiği bildirilmiştir. Burada yapılan değerlendirmelerde, vital bulgularının normal; çekilen elektrokardiyografinin normal olduğu, fizik muayenesinde solunum sistemi oskültasyonunda akciğer alt loblarında raller saptandığ1, başka patolojik bulgu olmadı̆̆ belirtilmiştir. $\mathrm{Bu}$ fizik muayene bulgusuna yönelik yapılan PAAC grafi görüntülemesinde ve toraks BT görüntülemesinde buzlu cam alanları saptanmıştır. Viral pnömoni tanısı ön planda tutularak alınan nazofarengeal sürüntü örneğinin COVID-19 PCR değerlendirmesi pozitif saptanması üzerine COVID19 tedavisinin başlandığı belirtilmiştir. Hastanın hıçkırığının devam etmesi sebebiyle tedavisine klorpromazin eklenmiş ve 12 saat sonra hıçkırığının kaybolduğu gözlenmiştir. Aynı sunumda, COVID19 tanısı aldıktan 15 gün sonra hastanede tedavi altındayken iki gündür kesilmeyen hıçkırığı olan 68 yaşında erkek hasta bildirilmiştir. Taburculuk esnasında hastanın hıçkırığına yönelik metoklopramid tedavisi verilmiş ancak iki gün sonraki başvurusunda hasta hıçkırığının devam ettiğini belirtmiştir. Yapılan değerlendirmeler neticesinde hastanın tedavisine klorpromazin eklenip tekrar kontrole çağrılmış ve hıçkırığının kaybolduğu gözlenmiştir. $\mathrm{Bu}$ sunumdaki iki vakada da hıçkırığın pnömoni ilişkili olabileceği vurgulanmiştır.

Burdette ve Marinella ${ }^{10}$ çalışmalarında; diyaframın üst kısmı ve sağ kalp sınırı boyunca yer alan frenik sinirin ve perikardiyal dallarının inflamatuar pnömoniye bağlı irritasyonunun hıçkırıkların patofizyolojik nedeni olabileceğini öne sürmüşlerdir. Bizim olgumuzda ise hıçkırık şikâyeti COVID-19 pnömonisi tespit edildikten sonra başlamıştır. Olgumuzdaki hıçkırığın COVID-19 pnömonisine bağlı inflamatuar irritasyonun bir sonucu olduğunu düşünmekteyiz.

Sonuç olarak; bu yazımız COVID-19 sonrası persistan hıçkırık şikâyeti olan ikinci olgu sunumudur (güncel literatür taramalarımıza göre). COVID-19 sonrası tabloların çeşitliliğinin arttığı bu günlerde, olgu sunumumuzun literatüre katkı sağlayacağını düşünüyoruz. Yapılacak çalışmalar COVID-19 sonrası gelişen hıçkırık patofizyolojisinin aydınlatılmasına katkı sağlayacaktır.

Etik Komite Onayı: Çalışma olgu sunumudur. Etik kurul belgesine gerek yoktur. Hastaya/yakınlarına bilgilendirilmiş gönüllü olur/onam formu imzalatılmış olup, çalışma uluslararası deklarasyona, kılavuza vb. uygun gerçekleştirilmiştir.

Çıkar Çatışması: Yazarlar çıkar çatışması bildirmemişlerdir.

Yazar Katkıları: Fikir - EE, MRA; Denetleme-EE, MRA; Malzemeler - EE, MRA; Veri toplanması ve/ veya işlemesi- EE, MRA; Analiz ve/veya yorum EE, MRA; Yazıyı yazan - EE, MRA.

Hakem Değerlendirmesi: Dış bağımsız.

\section{KAYNAKLAR}

1. Çevik B, Saraçoğlu KT, Bombacı E. Atypical presentation of COVID-19 cases: A case report and the literature review. South ClinIstanb Eu- 
rasia. 2020;31(Suppl):83-85. doi:10.14744/ scie. 2020.47704

2. Wang D, Hu B, Hu C, et al. Clinical characteristics of 138 hospitalized patients with 2019 novel coronavirus-infected pneumonia in $\mathrm{Wu}-$ han, China. JAMA. 2020;323(11):1061-1069. doi:10.1001/jama.2020.1585

3. Steger M, Schneemann M, Fox M. Systemic review: The pathogenesis and pharmacological treatment of hiccups. Aliment Pharmacol Ther. 2015;42(9):1037-1050. doi:10.1111/apt.13374

4. Chang FY, Lu CL. Hiccup: mystery, nature and treatment. J Neurogastroenterol Motil. 2012;18 (2):123-130. doi:10.5056/jnm.2012.18.2.123

5. Brikman S, Levi O, Dori G. Rare clinical manifestation of community-acquired pneumonia. BMJ Case Rep. 2018;11:e225589. doi:10.1136/ bcr-2018-225589

6. Nausheen F, Mohsin H, Lakhan SE. Neurotransmitters in hiccups. Springerplus. 2016;5 (1):1357. doi:10.1186/s40064-016-3034-3

7. Prince G, Sergel M. Persistent hiccups as an atypical presenting complaint of COVID-19. Am J Emerg Med. 2020;38(7):1546.e51546.e6. doi:10.1016/j.ajem.2020.04.045

8. Alvarez-Cisneros T, Lara-Reyes A, SansónTinoco S. Hiccups and psychosis: Two atypical presentations of COVID-19. Int J Emerg Med. 2021;14(1):8. doi:10.1186/s12245-021-00333-0

9. Ikitimur H, BorkuUysal B, Ikitimur B, et al. Case report: Two cases of persistent hiccups complicating COVID-19. Am J Trop Med Hyg. 2021;104(5):1713-1715. doi:10.4269/ajtmh.210190

10. Burdette SD, Marinella MA. Pneumonia presenting as singultus. South Med J. 2004;97 (9):915. 